\title{
THE IMPACT OF PRACTICUM TRAINING IN IMPROVING TEACHING COMPETENCES AMONG ABU DHABI UNIVERSITY POST-GRADUATE DIPLOMA STUDENTS -ANALYTICAL STUDY-
}

\author{
Tareq Al-Khasawneh ${ }^{1}$, Mohammad Ftieha ${ }^{2}$, Ghanem Al Bustami ${ }^{3}$ \\ ${ }^{1}$ Dr. Abu Dhabi University, UNITED ARAB EMIRATES, tareq.alkhasawneh@adu.ac.ae \\ ${ }^{2}$ Dr. Abu Dhabi University, UNITED ARAB EMIRATES, mohamed.ftieha@adu.ac.ae \\ ${ }^{3}$ Prof. Abu Dhabi University, UNITED ARAB EMIRATES, ghanem.albustami@adu.ac.ae
}

\begin{abstract}
Many trends have appeared in the field of teacher preparation all emphasizing the necessity to keep abreast of scientific, educational and technological developments. Part of such trends are developing curricula and identifying principles and guidelines for teacher preparation including: general, specialized and educational preparation, practicum training and practical education before and during the career. Current technological developments require teacher's mastery of how to deal with modern teaching methods such as computer software and internet and how to use them efficiently with the students. On these grounds, development of teacher preparation programs is essential to cater for society's developmental needs and respond to job market needs.

This study aims at exploring the degree of competence students of professional post-graduate diploma in teaching acquire from practicum training. The questions of the study are as follows:

What is the impact of Practicum program in improving students of professional post-graduate diploma teaching competences?

-What is the correlational relation between the practicum program competences and specialization?

-What is the correlational relation between the practicum program competences and students GPA?

An instrument of measuring the competences of practicum training was specially designed and used to answer the above questions with appropriate validity and reliability indicators. The sample of the study consisted of 264 students enrolled in the professional post-graduate diploma in teaching in the second semester 2013-2014. The statistical analysis of the data was carried out using SPSS program.

The findings indicated statistically significant differences in the attitudes of the students of the professional post-graduate diploma in teaching towards the impact of the Practicum program in improving students' teaching competences. The differences are attributed to the specialization variable. There are no statistically significant differences attributed to the cumulative grade point average. The study has a number of recommendations in light of the findings.
\end{abstract}

Keywords: Competences, Practicum, Teachers, Post-Graduate Diploma Program, Abu Dhabi University.

\section{INTRODUCTION}

Since teachers' role is vital, there are considerable efforts to qualify teachers to carry out their duties best. Such efforts can be before or during practicing the teaching profession as academic programs and training 
courses have equal importance and goals. They aim at developing teachers' skills and provide them with necessary teaching competences to become leaders of their classrooms, organizers of the teaching environments and designers of the teaching process. Teaching competences are various and include lesson planning, classroom management, classroom interaction and evaluation. New technologies entail new competences so that teachers can be abreast of modernity.

A teacher's role in the learning and teaching process is paramount and encompasses the entire education and socialization processes. This highlights the teacher's importance in the society being worthy of respect and recognition as a human, citizen and professional (Tartouri, 2007). In view of immense knowledge development and the multiple learning and teaching theories, the teaching profession has developed its own foundations, rules and methodologies. Many trends have appeared in the field of teacher preparation all emphasizing the necessity to keep abreast of scientific, educational and technological developments. Part of such trends are developing curricula and identifying principles and guidelines for teacher preparation including: educational preparation and practicum training before and during the career. Current technological developments require teacher's mastery dealing with modern teaching methods such as computer software and how to use them efficiently with the students. On these grounds, development of teacher preparation programs is essential to cater for society's developmental needs and respond to job market needs.

Teacher preparation is all about development of classroom performance. This trend depends upon the idea of teachers' competences on which preparation programs are based. In this respect, designated programs are developed with the aim of graduating teachers mastering these competences. Students of colleges of education are provided with varieties of theoretical and practical materials and experiences suitable to their majors and future duties. Preparation curricula designed for educators are selected and developed as per philosophical, social, religious and economic standards that fit their respective local societies (Freihat, 2013).

Practicum training is a student's real opportunity to be prepared as a teacher and provided with actual skills, practices and teaching experiences, especially when accompanied by effective supervision and guidance. Since practicum training is universally considered as the most important component of teacher preparation programs, it underwent improvements through enacted laws aiming at promoting its effectivity and prolonging its duration for a successful preparation of future teachers (Al Hadithi, 1998, p 114).

Practicum training represents an educational laboratory where students (future teachers) apply educational principles and theories in the field linking theory to practice (Faraj, 2004, p 65).

Through practicum training program, teacher preparation is assessed, the extent to which the program is successful is identified and teacher's behaviour is evaluated. The program also enables us to bridge the gap between theory and practice to apply basic skills in teaching and translate them to patterns (Al Omari and Al Massad, 1996, p 16).

\section{STATEMENT OF THE PROBLEM}

The Post-Graduate Diploma in Education program the Department of Education, College of Arts \& Science, Abu Dhabi University aims at supplying the community with qualified teachers. The mission of the program is to offer an academic program in educational qualification to holders of bachelor degrees in science, humanities and social and Islamic studies in order to have academically, culturally and educationally qualified teachers contributing to the promotion of the teaching profession and satisfy the needs of the community in all fields of knowledge.

The significant development of the program over the past years in quality and quantity and increased enrolment incited researchers to study the impact of the practicum training program on improving educational competences of the ADU post-graduate diploma in education students. The program has been in operation for ... years, however, no study has been conducted so far to evaluate its effectiveness in enhancing the teaching competencies of the students. Studying such competences will help the development of the program.

This implies the study problem of identifying the impact of practicum training in improving teaching competences among ADU post-graduate diploma students and the impact of the variables of specialization and grade point average (GPA) on these competences.

\section{THE PURPOSE OF THE STUDY}

The current study aims at identifying the impact of practicum training in improving teaching competences among ADU post-graduate diploma students through answering the following main question:

1. What is the impact of practicum training in improving teaching competences among ADU post-graduate 
diploma students? This question leads to the following two sub-questions:

Are there any differences of statistical significance in the impact of practicum training in improving teaching competences among ADU post-graduate diploma students attributed to specialization?

- $\quad$ Are there any differences of statistical significance in the impact of practicum training in improving teaching competences among ADU post-graduate diploma students attributed to grade point average (GPA)?

\section{STUDY HYPOTHESES}

1. There are no significant statistical differences at the significance level $(0.050=a)$ in the impact of practicum training in improving teaching competences among ADU post-graduate diploma students attributed to specialization.

2. There are no significant statistical differences at the significance level $(0.050=a)$ in the impact of practicum training in improving teaching competences among ADU post-graduate diploma students attributed to grade point average (GPA).

\section{IMPORTANCE OF THE STUDY}

The importance of the study lies in the following points:

1. The urgent need to prepare the teacher in a way that match the scientific, educational and technological development enabling him of providing an attractive educational environment. To this end, it should be ascertained that the teacher acquires teaching competences ensuring the realization of intended educational goals.

2. Providing a feedback of the effectivity of the practicum training program in developing teaching competences for its enrolled students in order to be amended or developed in light of the findings.

3. The results of this study may be of benefit to prepare recommendations and suggestions of interest to universities and ministries that are concerned with offering practicum training programs.

\section{OPERATIONAL DEFINITION OF TERMS}

Competencies: The abilities to possess knowledge and use it in performing the teaching - learning skills related to this knowledge and to apply the same in teaching - learning situations within a specific level of performance and specific time. In this study, they mean the total grade which the respondent on the list of teaching competencies whom was employed by researchers for the purpose of this study.

Practicum: A specialized training within the post-graduate diploma in teaching program at the Department of Education, College of Arts and Sciences at Abu Dhabi University. It gives the teacher an opportunity to practice education at schools for one semester four days a week under the supervision of academic professionals and cooperating supervisors.

Students of the Educational Qualification Program: Students who joined the said program in Abu Dhabi University to obtain the Educational Qualification Diploma in teaching.

Post Graduate Diploma in Teaching: One of the programs in the College of Arts and Sciences, Department of Education in Abu Dhabi University, which aims at graduating teachers educationally qualified to work in the profession of teaching.

Abu Dhabi University: an independent private academic institution based in Abu Dhabi, the capital city of the United Arab Emirates. It was established in 2003 and is considered one of the leading universities in the country. It obtained regional and international recognitions and thus became one of the strong competitors in providing students with knowledge.

\section{LITERATURE REVIEW}

This section provides information about some studies that have been conducted related to the problem of the present study. The studies are arranged chronologically from oldest to newest.

There is a study by Gzeiwat 2005 that aimed at identifying the most prominent competences of teachers majoring at Field Teacher in Social Studies, Mo'ta University, as perceived by cooperating social studies teachers in Karak governorate's schools, Jordan. The researcher used the descriptive method and a questionnaire the validity and reliability of which were confirmed to be at the degree of 78,0 through repeated use. The researcher used means, percentages and tests (TEST.T) due to their being appropriate 
for the study goals. The questionnaire was distributed to 40 subjects (male and female teachers). The results showed that students of social studies needed some competences such as: knowledge and personal refreshment, organizing self-learning, classroom management and using modern teaching methods. The study recommended providing the students with some competences such as: modern teaching methods, competence of evaluation, competence of self-learning and competence of classroom management.

A study of Shatnawi, 2007 aimed to identify the most prominent competences of female teachers / field teacher (literary and scientific) at the College of Education in Abra, Sultanate of Oma as perceived by cooperating teachers at the schools of the governorate of Al Dhahirah - South. The researcher used the descriptive method and a questionnaire the validity and reliability of which were confirmed to be at the degree of $86 \%$ through using Cronbach's alpha formula. The questionnaire was distributed to 60 subjects (female teachers). The results showed that the female teachers needed some competences such as: knowledge and personal refreshment, organizing self-learning and using modern teaching methods. He recommended providing practicum education programs at the college focusing on preparing and qualifying teachers, and providing the students with some competences such as: modern teaching methods, competence of self-learning, competence of creating an atmosphere of freedom and safety for students in the classroom.

The study by Abu Shandi et al, 2009 aimed at evaluating the practicum program at Zarqa Private University in terms of the superintendent, cooperating teacher, principal, cooperating school and the procedures of the practicum program as perceived by students (teachers). The study also aimed at investigating the impact of variables of gender, place of training, student's GPA and student's evaluation of the fields of practicum program. The study sample consisted of 96 male and female students selected through purposive sampling. The instrument was a questionnaire of 59 paragraphs. According to the results, students' evaluation of the fields of practicum program are as the following: the evaluation of the practicum education superintendent was the highest, followed by that of cooperating teacher, the procedures of the practicum program, the cooperating school and finally the principal.

The study by Khawlda et al 2010 aimed at finding out the problems facing students (teachers) in the specialization of child education, Queen Rania Faculty of Childhood, the Hashemite University during practicum education. To achieve the study objective, a questionnaire of 52 paragraphs and six fields was developed. It was distributed to 100 students (teaches). Results showed that practicum education problems faced by students (teachers) are as follows (ordered according to strength):

Problems related to cooperating kindergarten, practicum education program, personality of student (teacher), supervision of practicum education, cooperating female teacher and planning and execution of lessons. In light of the results, the researchers recommended the development of a practicum education program as per international standards and setting strategies to overcome the problems facing students (teachers), especially those related to the role of kindergarten and carrying out more research in relevance to these problems.

Lori Simons et al 2012 conducted a study aiming at I exploring the lessons learnt from field experiences and what a student learns from practicum education. Researchers used a sample of 38 students enrolled in practicum education program. Results of the study showed an improvement to students' cultural skills. It also showed that experiential learning enhanced personal experiences and loyalty. Superintendents and students stated that practicum education is useful for community partnership.

The study of Sibel Yes, ildere I'mre and Hatice Akkoc, 2012 aimed to know what faculties should students (teachers) have in order to perform better teaching of mathematics during practicum education. The researchers used Radford's framework and found out that students (teachers) should be capable of being aware of understanding their students and the problems they face and the strategies of teaching and performing lessons of mathematics.

The study of L. Grundoff, 2012 aimed at knowing the role played by practicum education in moving from the stage of preparation to the stage of practicing teaching. The researcher used qualitative research method with 12 novice teachers in New Zealand. The study showed that although novice teachers consider practicum education as an integral part of preparation, their field experiences were not always useful in supporting their mobility in teaching. The study recommended reconsidering the practicum education program in order to have teachers prepared to face requirements and complications of the teaching profession.

Al Shahri and Mohammad 2013 carried out a study aiming at identifying strengths and weaknesses of practicum education program and what faculty members and female students think about the program. The study used the analytical descriptive method and a questionnaire as an instrument. More than $80 \%$ of the 
sample agreed on the tasks of the practicum education supervisor, that the objectives of practicum education do not cope with educational development and there is no guidebook for practicum education to explain practicum training plan.

The study of Kline, J., White, S., \& Lock. G, 2013 aimed at reviewing the preparation of quality teachers working in rural areas of Australia. The descriptive survey was used for the study which included a sample of 263 respondents. It was found out that professional experience is a key component of confidence to work in such areas, partnership between schools, assemblies and government provides a solid ground to improve rural students and contributes to strengthening the community and successful field experiences are likely to affect positively on students' (teachers) motivation and commitment to the teaching profession.

It is clear from the previous studies that the differences of the results are attributed to the differences of the variables studied. It is also clear that most of the previous studies were carried out on male and female students of colleges of education and a few of them on students of post-graduate diploma in education. What distinguish this study is the variables studied. It includes the variables of specialization and GPA and is carried out on a special sample of post-graduate diploma in education, which is specialized in preparing teachers of all specializations.

\section{LIMITATIONS OF THE STUDY}

The results of this study shall be limited to the special conditions of the sample in respect of its size, features, the method of its choice and the instrument of the study in respect of the procedures of its development and its psychometric features and the methods of collecting information and statistical analysis.

\section{STUDY POPULATION AND SAMPLE}

The population of the study consisted of all the 363 students enrolled in the Post-Graduate Diploma in Education Program in the academic year 2013-2014. The researchers distributed questionnaires to all mentioned participants. A total of 264 completed questionnaires were received which accounted for $73 \%$ of the response rate. Table (1) shows the distribution of the members of the study sample according specialization and GPA.

Table No. 1

Distribution Of Participants According To The Study Variables.

\begin{tabular}{|l|c|c|c|}
\hline Variable & Variants Categories & No. & Percentage \\
\hline \multirow{3}{*}{ Specialization } & Literary & 114 & 43.2 \\
\cline { 2 - 4 } & Scientific & 132 & 50.0 \\
\cline { 2 - 4 } & No Answer & 18 & 6.8 \\
\hline \multirow{4}{*}{ GPA } & Excellent & 147 & 55.7 \\
\cline { 2 - 4 } & Very Good & 71 & 26.9 \\
\cline { 2 - 4 } & Good & 7 & 2.7 \\
\cline { 2 - 4 } & Less than good & 1 & 04 \\
\cline { 2 - 4 } & No answer & 38 & 14.4 \\
\hline
\end{tabular}

\section{STUDY INSTRUMENT}

The list of education competencies which was prepared by Landers \& Weaver 1991 and developed by Haroon (1995), was used. The list includes 32 teaching competencies, Landers \& Weaver made sure of the content validity of the list by presenting it to 10 arbitrators who are specialized in education to ascertain that the paragraphs are relevant to the study, clear, of correct language, coherent and inclusive of the different aspects of the practicum training program. There was $90 \%$ consensus among the arbitrators in respect of all paragraphs, and therefore the list was used as is; nevertheless, few changes were made according to some comments.

The internal consistency reliability of the paragraphs of the scale was verified by applying it to an exploratory sample of 50 students of the Educational Qualification Diploma at Abu Dhabi University. The Correlation Coefficient ranged between each paragraph and the total degree between $0.24-0.73$. Table (2) shows the results of the internal consistency reliability. 
IJAEDU- International E-Journal of Advances in Education, Vol. IV, Issue 10, April 2018

Table (2) Internal Consistency Reliability Of The Teaching Competences Instrument

\begin{tabular}{|l|l|l|l|l|l|l|l|l|l|l|l|}
\hline Item & $\begin{array}{l}\text { Correlati } \\
\text { on } \\
\text { Coeffici } \\
\text { ent }\end{array}$ & Item & $\begin{array}{l}\text { Corre } \\
\text { lation } \\
\text { Coeffi } \\
\text { cient }\end{array}$ & Item & $\begin{array}{l}\text { Correl } \\
\text { ation } \\
\text { Coeffic } \\
\text { ient }\end{array}$ & Item & $\begin{array}{l}\text { Correl } \\
\text { ation } \\
\text { Coeffic } \\
\text { ient }\end{array}$ & Item & $\begin{array}{l}\text { Correla } \\
\text { tion } \\
\text { Coeffic } \\
\text { ient }\end{array}$ & Item & $\begin{array}{l}\text { Correlation } \\
\text { Coefficient }\end{array}$ \\
\hline 1 & ${ }^{* *} 0.51$ & 7 & ${ }^{* *} .70$ & 13 & 0.37 & 19 & 0.57 & 25 & ${ }^{* *} 0.57$ & 31 & ${ }^{* *} 0.59$ \\
\hline 2 & ${ }^{* *} 0.50$ & 8 & 0,24 & 14 & 0.36 & 20 & ${ }^{* *} 0.57$ & 26 & 0.49 & 32 & ${ }^{*} 0.65$ \\
\hline 3 & ${ }^{* *} 0.55$ & 9 & 0.43 & 15 & 0.47 & 21 & ${ }^{* *} 0.63$ & 27 & 0.33 & & \\
\hline 4 & ${ }^{* *} 0.56$ & 10 & $\begin{array}{l}{ }^{* *} 0.6 \\
1\end{array}$ & 16 & ${ }^{*} 80.5$ & 22 & $\begin{array}{l}{ }^{*} 80.7 \\
3\end{array}$ & 28 & 0.47 & & \\
\hline 5 & ${ }^{* *} 037$ & 11 & ${ }^{* *} 0.6$ & 17 & 0.38 & 23 & 0.44 & 29 & ${ }^{* *} 0.36$ & & \\
\hline 6 & ${ }^{* *} 0.53$ & 12 & 0.45 & 18 & ${ }^{* *} 0.57$ & 24 & ${ }^{* *} 0.68$ & 30 & ${ }^{* *} 0.63$ & & \\
\hline
\end{tabular}

It becomes clear from Table (2) that the correlation coefficients of the scale items with the total degree are high proving that the instrument has accepted indications to be used in the study.

To measure the extent of the reliability of the measurement instrument, Cronbach's alpha test was used where alpha value $=95 \%$ which is a high percentage and agrees with the previous percentages .

A 5 - point Likert-type scale was used for the questionnaire items and which were graded from the very low degree to the very high degree. Moreover, the following grades were given to each response $(1,2,3.4 .5)$ respectively. If the response for example is very low, it is given (1) if it is low, it is given (2), if it is average, it is given (3) and if it is high, it is given (4), and it is given (5) if it is very high. Therefore, the highest grade that can be obtained on the instrument is (160) which represents very high degree of acquisition, and the least grade is (32) which represents a very low degree of competence. Since the aim of the study is to define the extent of students' acquisition of teaching competencies, researchers have defined grade (4) as the minimum accepted grade since the student possesses the competency. This standard was approved because the students were still under training and do not have enough experience in teaching. The length of the numerical category of the means of the items and the instrument as a whole is calculated by subtracting the minor correction key from the major correction key and to divide the result into the number of categories of the instrument and its value was (0.8) as it is shown in Table No. (3).

Table No. (3): The Numerical Categories of the Means and the percentages of the acquisition degrees

\begin{tabular}{|l|c|l|}
\hline Correction Key & Acquisition Degree & Category of the Means \\
\hline 1 & Very Low & $1.0-1.799$ \\
\hline 2 & Low & $8-2.599$ \\
\hline 3 & Medium & $2.6-3.399$ \\
\hline 4 & High & $3.4-4.199$ \\
\hline 5 & Very high & $4.2-5.0$ \\
\hline
\end{tabular}

The researchers distributed the questionnaire to the students and gave them the needed time to respond, and then the questionnaires were collected by the researchers themselves.

\section{STUDY DESIGN \& THE STATISTICAL TREATMENT}

To answer the study questions, the statistically obtained data was analyzed by using SPSS. The means of the grades obtained by the study sample were extracted for each paragraph of the instrument by the indication of the model answers and their standard deviations. To describe the responses of the sample and to answer the sub- questions of the study, the One Way ANOVA (One-Way Analysis of Variance) was used.

\section{RESULTS}

This study aimed to study identifying the impact of practicum training program in improving teaching competences among ADU post-graduate diploma in education and finding out whether the impact of the practicum training program is affected by variables of specialization and grade point average (GPA).

To answer the first question of this study, "What is the impact of practicum training in improving teaching 
competences among ADU post-graduate diploma students? The mean and the standard deviation were extracted to describe the responses of the sample to the items below:

Table (4)

The Means \& Standard Deviations And The Degree Of The Acquisition Of The Teaching Competencies Of The Study Subjects' Responses To The Teaching Competences Questionnaire

\begin{tabular}{|c|c|c|c|c|c|}
\hline Rank & No & The Question & Mean & $\begin{array}{l}\text { S- } \\
\text { Deviation }\end{array}$ & $\begin{array}{l}\text { Acquisition } \\
\text { degree }\end{array}$ \\
\hline 1 & 27 & $\begin{array}{l}\text { To make myself a good example during social } \\
\text { interaction with my students inside the classroom. }\end{array}$ & 4.2159 & 0.7913 & Very High \\
\hline 2 & 31 & $\begin{array}{l}\text { Social interaction with students showing positive } \\
\text { appreciation to themselves. }\end{array}$ & 4.2045 & 0.8341 & Very High \\
\hline 3 & 29 & $\begin{array}{l}\text { To provide the natural environment inside the } \\
\text { classroom characterized by safety, appropriateness } \\
\text { and easy movement. }\end{array}$ & 4.0947 & 0.8734 & High \\
\hline 4 & 32 & $\begin{array}{l}\text { Provide and distribute proper time when teaching } \\
\text { different academic areas. }\end{array}$ & 4.0758 & 0.8774 & High \\
\hline 5 & 28 & $\begin{array}{l}\text { Prepare the classroom environment making all } \\
\text { students feel having equal chances. }\end{array}$ & 4.0568 & 0.9237 & High \\
\hline 6 & 14 & $\begin{array}{l}\text { Evaluate the lesson through the use of required } \\
\text { social and communicative skills }\end{array}$ & 0.453 & 0.8347 & High \\
\hline 7 & 5 & $\begin{array}{l}\text { Phrasing the observable and measurable behavioral } \\
\text { objectives }\end{array}$ & 4.0417 & 0.9199 & High \\
\hline 8 & 17 & $\begin{array}{l}\text { Applying various Reinforcement systems during the } \\
\text { period. }\end{array}$ & 4.0265 & 1.0623 & High \\
\hline 9 & 7 & $\begin{array}{l}\text { Provide a teaching environment that provides } \\
\text { students with information about their behavioral } \\
\text { performance (Feedback) }\end{array}$ & 4.0114 & 0.811 & High \\
\hline 10 & 1 & $\begin{array}{l}\text { Provide a teaching - leaning environment that } \\
\text { encourages students to active participation in the } \\
\text { various learning activities. }\end{array}$ & 3.9735 & 0.9368 & High \\
\hline 11 & 25 & $\begin{array}{l}\text { Understand a group of extraordinary behavioral } \\
\text { methods displayed by students inside the classroom } \\
\text { such as absent - mindedness, introversion, } \\
\text { aggression and hyperactivity. }\end{array}$ & 3.9621 & 0.9097 & High \\
\hline 12 & 13 & $\begin{array}{l}\text { Evaluate the lesson through a learning environment } \\
\text { which provides some care and acceptance, }\end{array}$ & 3.9508 & 0.9277 & High \\
\hline 13 & 19 & $\begin{array}{l}\text { Applying various strategies during lesson } \\
\text { presentation. }\end{array}$ & 3.947 & 0.9657 & High \\
\hline 14 & 18 & $\begin{array}{l}\text { Applying various strategies during the first learning } \\
\text { stages as a stage of acquisition. }\end{array}$ & 3.8674 & 1.0176 & High \\
\hline 15 & 30 & $\begin{array}{l}\text { Implementing a programs that gives the disable SS } \\
\text { the chance of interacting with their healthy } \\
\text { counterparts. }\end{array}$ & 3.8485 & 1.0169 & High \\
\hline 16 & 8 & Applying the strategies of teaching small groups & 3.8106 & 0.9443 & High \\
\hline 17 & 26 & $\begin{array}{l}\text { Organizing and treating the transitional periods } \\
\text { between activities actively. }\end{array}$ & 3.8106 & 0.9443 & High \\
\hline 18 & 24 & $\begin{array}{l}\text { Understanding the principles of general } \\
\text { development of the disabled and the normal }\end{array}$ & 3.7992 & 1.0176 & High \\
\hline 19 & 16 & Using different learning groups inside the classroom & 3.7917 & 1.0743 & High \\
\hline 20 & 22 & $\begin{array}{l}\text { Recognizing the various educational applications of } \\
\text { the simple academic disabilities related to } \\
\text { evaluation and planning processes. }\end{array}$ & 3.7841 & 0.9284 & High \\
\hline 21 & 11 & $\begin{array}{l}\text { Organizing different child- centered expertise which } \\
\text { requires active participation on his part. }\end{array}$ & 3.7803 & 0.9774 & High \\
\hline 22 & 9 & $\begin{array}{l}\text { Implementing teaching model based on organized } \\
\text { instruction }\end{array}$ & 3.7689 & 0.9767 & High \\
\hline
\end{tabular}


IJAEDU- International E-Journal of Advances in Education, Vol. IV, Issue 10, April 2018

\begin{tabular}{|l|l|l|l|l|l|}
\hline 23 & 23 & $\begin{array}{l}\text { Applying the rules of meetings that give good } \\
\text { impression on the part of parents, officials and } \\
\text { specialists when meeting with them }\end{array}$ & 3.7652 & 1.0847 & High \\
\hline 24 & 12 & $\begin{array}{l}\text { Using technical aids so as to make teaching as } \\
\text { such self-learning }\end{array}$ & 3.7538 & 1.1185 & High \\
\hline 25 & 2 & $\begin{array}{l}\text { To plan different teaching activities that suit } \\
\text { students of special needs simple academic needs. }\end{array}$ & 3.75 & 0.9423 & High \\
\hline 26 & 20 & $\begin{array}{l}\text { To know the legislative procedures which guarantee } \\
\text { the disable right to receive his education with his } \\
\text { normal peers. }\end{array}$ & 3.7159 & 1.0921 & High \\
\hline 27 & 6 & $\begin{array}{l}\text { To test and develop addition materials that } \\
\text { complete the curriculum }\end{array}$ & 3.7045 & 1.059 & High \\
\hline 28 & 15 & $\begin{array}{l}\text { Applying the individual instructional strategies } \\
\text { Using the techniques of behavior adjustment to treat } \\
\text { SS behavioral disorders }\end{array}$ & 3.66629 & 1.1448 & High \\
\hline 30 & 4 & $\begin{array}{l}\text { To recognize the basic needs which if not fed up , } \\
\text { will not cause the sudden behavioral changes on } \\
\text { the part of the student }\end{array}$ & 3.6515 & 0.9749 & High \\
\hline 31 & 10 & $\begin{array}{l}\text { The choice of teaching introductions that suit the } \\
\text { inclinations and motives of each student separately. }\end{array}$ & 3.6212 & 1.1136 & High \\
\hline 32 & 3 & $\begin{array}{l}\text { To prepare the individual educational plans which } \\
\text { are based on analyzing the task into small teaching } \\
\text { steps, }\end{array}$ & 3.6136 & 1.1838 & High \\
\hline & \begin{tabular}{l} 
General Average \\
\hline
\end{tabular}
\end{tabular}

It can be noticed from Table (4) that the means of the answers of the sample members to the scale items range between 3.6136 with a standard deviation of 1.1838 \& and 4.2159 with a standard deviation of 0.7913 . With the help of Table ( 3 ) it becomes clear that items of ranks $2 \& 2$ have attained means arranged descending from 4.2045 to 4.2159 with a very high acquisition grade of improving teaching competencies among ADU post-graduate diploma students, whereas the items of ranks 3 and 32 have obtained means arranged ascendingly from 3.6136 to 4.0947 within a high acquisition grade of improving teaching competencies among ADU post-graduate diploma students. It is to be noted that the general direction of the instrument a mean of 3.868 and s standard deviation of 59965.To know the mean of response of the members in the sample and the extent of its statistical significance, the T-Test was used for one sample and it was found out that there are differences of statistical significance between the test and the theoretical mean which equals 3 as it is shown in Table (5) below:

Table No. (5): The T-Test for One Sample

\begin{tabular}{|c|c|l|l|l|l|l|}
\hline Mean & \multicolumn{6}{|c|}{ Null Hypothesis } \\
\cline { 2 - 7 } & $\begin{array}{c}\text { T- } \\
\text { Value }\end{array}$ & $\begin{array}{l}\text { Freedo } \\
\mathrm{m} \\
\text { Degree }\end{array}$ & $\begin{array}{l}\text { Significan } \\
\mathrm{ce}\end{array}$ & $\begin{array}{l}\text { Difference between the } \\
\text { sample center and null } \\
\text { hypothesis }\end{array}$ & \multicolumn{2}{l}{$\begin{array}{l}\text { Center } \\
\text { Confidence } \\
\text { Interval }\end{array}$} \\
\cline { 5 - 7 } & $\begin{array}{l}23.52 \\
9\end{array}$ & 263 & 0.000 & .86837 & .7957 & 09410 \\
\hline
\end{tabular}

From Table (5) it can be noticed that there are differences of statistical significance at the confidence level 0.05 , and this means that the percentage of the students who acquired the competencies was $100 \%$ and this is because the category of the mean 3.399.206 was taken as "y-intercept" since the students of the Educational Qualification Diploma are not specialists in special education and consequently the means of all the members of the sample higher than3.6136.

To answer the sub-questions which emerge from the main question of the study, the hypothesis of each question was tested. In respect of the first sub- question : "What is the correlational relation between the practicum program competences and field of specialization?" .The hypothesis of this question was" There are no differences of statistical significance at the confidence level ( $0.05=a)$ in impact of practicum training in improving teaching competences among ADU post-graduate diploma students which are attributed to specialization. To answer this question and to verify or check its hypothesis, the T-Test was used for two 
independent samples, and Table No (6) shows the results of this analysis.

Table No. (6)

T-Test Of The Variable Of Specialization On The Total Degree Of The Acquisition Of The Teaching Competencies Required For Post-Graduate Diploma Students.

\begin{tabular}{|l|l|l|l|l|}
\hline Specialization & Mean & \multicolumn{2}{|l|}{$\begin{array}{l}\text { T-Test of Means } \\
\text { equality }\end{array}$} & \multirow{2}{*}{} \\
\cline { 3 - 4 } & & & & \\
\hline Literary & 4.0192 & 244 & 4.227 & Sigm (2-tailed) \\
\hline Scientific & 3.7034 & 242.741 & 4.250 & 0.000 \\
\hline
\end{tabular}

It is clear from Table ( 6 ) that the calculated $T$ value $=4.227$, and $\mathrm{df}=244$, and the value 2- Sig ( $0.000=$ tailed ) which means the rejection of the zero hypothesis, that is , there are differences of statistical significance between the means in favor of the literary specializations and this is because their mean is bigger .

To answer the second sub-question, namely " What is the correlational relation between the practicum program competences and students GPA? , since the special hypothesis of this question was " There are no differences of statistical significance at the confidence level $(0.05=a)$ in impact of practicum training in improving teaching competences among ADU post-graduate diploma students which are attributed to students GPA". The One-way - ANOVA was used to now whether there are differences of statistical significance attributed to students GPA, where Table 7 shows the results of this analysis.

Table No. (7)

Test of ". The One-Way - ANOVA To Difference Significance In The Acquisition Of Teaching Competencies Of Post-Graduate Diploma Students Which Are Attributed To GPA

\begin{tabular}{|l|l|l|l|l|l|l|l|}
\hline & $\begin{array}{l}\text { Total of } \\
\text { Quarters }\end{array}$ & \multicolumn{1}{|c|}{ DF } & $\begin{array}{l}\text { Quarters } \\
\text { Mean }\end{array}$ & F Value & $\begin{array}{l}\text { Sig. } \\
\text { value }\end{array}$ & $\begin{array}{l}\text { Result of } \\
\text { zero } \\
\text { Hypothesis }\end{array}$ & $\begin{array}{l}\text { Tabulated } \\
\text { Value }\end{array}$ \\
\hline $\begin{array}{l}\text { Between } \\
\text { groups }\end{array}$ & 7.357 & 2 & 3.678 & 11.008 & .000 & 1.46 & \\
\hline $\begin{array}{l}\text { Inside } \\
\text { Groups }\end{array}$ & 87.212 & 261 & .334 & & & & \\
\hline Total & 94.568 & 263 & & & & & \\
\hline
\end{tabular}

It becomes clear from Table ( 7 ) that there are no difference of statistical significance at the level of ( Alpha $=0.05)$ in the acquisition of teaching competencies of the ADU post-graduate diploma students which are attributable to GPA.

\section{RESULTS DISCUSSION}

The results of the study which are related to the first question in respect of the degree of acquisition teaching competencies of the students who are studying the practicum course as shown in the tables above that maintain that the degree of the acquisition of the teaching competencies on the part of the ADU postgraduate diploma students ranged between high and very high. This indicates the importance of the practicum course in improving teaching competences among adu post-graduate diploma students. This results from the fact that practicum links theory to practice; as the different courses studied by a student prior to their joining field training at school have notable impact on the appropriate academic and educational preparation of a teacher and thus achieving the aspired educational outcomes. Moreover, such competences add self-confidence to trainees to join the educational profession more effectively and ably. These results are in line with the results found by Lori Simons 2012 and L. Grudnoff, 2012; whereas they contradict the results found by Gzeiwat 2005 and Shatnawi 2007.

As regards the first sub-question which indicated differences of statistical significance in favor of the literary against scientific specializations. Researchers attribute this to the fact that literary specializations deal with tangible more than abstract issues; and therefore, this facilitates using various teaching methods, activities and aids leading to higher educational effectivity as compared with scientific specializations.

As regards the second sub-question, "What is the correlational relation between the practicum program 
competences and students GPA?" which indicates that there are no difference of statistical significance at the level of (Alpha $=0.05$ ) in the acquisition of teaching competencies of the ADU post-graduate diploma students attributable to GPA. Researchers attribute this result to the fact that the GPA depends mainly upon students' acquisition of theoretical knowledge through their studying of the post-graduate professional diploma and not necessarily upon their ability of practice during practicum.

\section{RECOMMENDATIONS}

In the light of the results of this study it recommends the following:

1- To increase and give more attention to practicum courses which providing training programs for teachers preparation and to train them within the programs of the Faculties of Education in the UAE universities to prepare specialized national frames and qualify them in the field of education due to the lack of specialized educational programs to prepare teachers for such groups of students. The study proved that such courses provide a reasonable number of competencies for students.

2- It is necessary to qualify teachers educationally through encouraging them to enroll in the educational qualification programs for the competencies and skills provided by these programs.

3- Coordination with the Ministry of Education to provide on-going training programs for in- service teacher, programs that cover the mechanisms of recognizing the educational obstacles and the methods of dealing with the teaching needs of these groups of students.

4- To conduct and carry out more studies and research dealing with other variables such as: educational stage, type of schools (public or private)... etc.

\section{REFERENCE LIST}

Abu Shandi, Yousef Abdul Qader \& Abu Sha'eer, Khaled Mohammad \& Aqari, Thaer Ahmad (2009). Practical Education Program Evaluation. Zarqa University, Jordan, Zarqa Journal for Humanities Research and Studies, (9) (1).

Al Hadithi, Saleh bin Soleiman bin Mohammad. (1998). Reality of Field Educational Supervision in the College of Education, King Saud University, Riyadh, Arabian Gulf Message, Arab Education Office of the GCC Countries.

Al Omari, Khaled, and Massad, Mohammad (1996). Practical Education: Theoretical Framework. Sanaa, Yemen: Ministry of Education.

Al Shahri, Amal Dhafer and Mohammad, Lamyaa Jalal (2013). Evaluation of Practical Education for Female Students of Level 8 as perceived by Faculty Members and Students of the College of Education of Najran University. Arab Studies in Education and Psychology, Issue 39, 91-121.

Citation: Kline, J., White, S., \& Lock, G. (2013). The rural practicum: Preparing a quality teacher workforce for rural and regional Australia Journal of Research in Rural Education, 28(3), 1-13.

Faraj, Abdul Latif bin Hussein. (2004). Basic Aspects to Evaluate Teacher Student as Perceived by Supervisors and Cooperating Teachers. Studies in University Education, Ain Shams University.

Freihat, Ammar (2013). Extent of Contribution of Practical Education to Providing Female Students of Child Education at Ajloun University College with Teaching Competences from their Point of View, Journal of Islamic University for Educational and Psychological Studies, Vol. 21, Issue: 1, pp 151-175.

Gzeiwat, Mohammad Ibrahim (2005). Teaching Competences Enjoyed by Teachers Studying the Major of Field Teacher/ Social Studies at Mo'ta University, form the Point of View of Cooperating Teachers of Social Studies at Karak Governorate Schools, Jordan. Umm Al Qura Journal for Educational and Social Sciences and Humanities, (14) (1).

Khawaldeh Mostafa and Ehmeida, Fat'hi (2010). Identifying the Problems Facing Student Teachers Specialized in Child Education at Queen Rania Faculty of Childhood, the Hashemite University, Journal of Damascus University (26) (3).

Lori Simons, Lawrence Fehr, Nancy Blank, Heather Connell, Denise Georganas, David Fernandez, and Verda Peterson (2012) Lessons Learned from Experiential Learning: What Do Students Learn from a Practicum/Internship? International Journal of Teaching and Learning in Higher Education, 2012, 
Volume 24, Number 3, 325-334.

Shatnawi, Abdulkareem Mohammad (2007). Competences of Female Teachers / Field Teacher (Literary and Scientific) at the College of Education in Abra, Sultanate of Oman as Perceived by Cooperating Teachers at the Schools of the Governorate of AI Dhahirah - South of Oman. Journal of Educational and Psychological Studies, Sutlan Qaboos University (1).

Sibel Yes, ildere I'mre, and Hatice Akkoc (2012). Investigating the development of prospective mathematics teachers' pedagogical content knowledge of generalising number patterns through school practicum. $\mathrm{J}$ Math Teacher Educ (2012) 15:207-226.

Tartouri, Mohammad Awad (2007). Teacher Preparation and Qualification at Modern Educational School, Minshawi Forums for Research and Studies. Available online: http://minshawi.com 